DOI: $10.15642 / J I I S .2016 .10 .2 .285-308$

\title{
CURRICULUM, ISLAMIC UNDERSTANDING AND RADICAL ISLAMIC MOVEMENTS IN INDONESIA
}

\author{
Husniyatus Salamah Zainiyati \\ UIN Sunan Ampel Surabaya - Indonesia | husniyatus@yahoo.com
}

\begin{abstract}
This article is intended to argue several things. The first is that the educational institutions can play two roles within the context of transmitting Islamic understanding; either to preach the tolerance or in contrast the radicalism. The second is that the teachers affiliated to certain radical movements often fall in to corrupt practices by abusing the school curriculum, which actually is aimed at providing guideline for the teachers of Islamic Religion in order to promote characters of students in line with the values of Indonesia Islam. The third is that the condition and the environment of schools tend to allow the room for the deployment process of radical movements in Indonesia. This article will explore issues on the relationship between school curriculum and radicalism, the transmission of Islamic understanding as well as possible solutions for overcoming the spread of radicalism. In conclusion, this article will reinforce ideas that teachers are the most important instruments within the curriculum implementation. In this regards, it is important to note that curriculum in its various forms is just a text and hence the teachers are the ones really determine the ways in which it is being read and interpreted. It is suggested then that there is a duty that should be performed by the government to strengthen their ideology based on the country national guidelines embraced by Muslims in Indonesia.
\end{abstract}

Keywords: Curriculum, Islamic Understanding, Radicalism

\section{Introduction}

The rise of terrorist acts lately in Europe, America and Asia, including in Indonesia, has restored the memory of all people of the danger of the tenet of the the radical islamic movements and their radical acts. The reason is very simple. It is all because in any act of 
terror, printed and electronic media, directly link the terror acts with Islamic religious movements which tend to embrace radicalism. Experts believe that the danger of this movement is characterized by the strong indoctrination by the perpetrators' (members of the radical islamic moverments) to their followers. Various indoctriniation techniques have been implemented by them. Therefore, eliminating those movements is not an easy effort to do. The fact is that, until today, radical islamic movements in its various forms are still widespread wordlwide in almost all countries.

Apart from global movement, the growing intensity of terrorist behavior also indicates the failure of de-radicalization program in Indonesia; be it in the form of reindoktrination for former terrorists by promoting more tolerant understanding, or preventive measures to ward off the spread of radical Islam, through various approaches such as counter-movement in the social, political and economic. For example, Afif and Kurnia, the two persons committing terror acts in the Hotel Sarinah Jakarta in the early 2016, are the convicted terrorists arrested in 2010 after committing terror acts in Aceh. Although they have been undergoing the deradicalization program during their time in jail in Jakarta, it is clear that their radical mindset has not changed yet. ${ }^{1}$ Another example is Santosa or also known as Abu Wardah, a veteran terrorist. After being convicted terrorist and been jailed for robbery and shooting of police officers in 2011 in Palu, he still continues his radical activities and lead the ISIS movement in the eastern parts of Indonesia as well as spreading terror in several regions in Indonesia. Eventually, he was shot dead in Juli 2016. ${ }^{2}$

Unsurprisingly, one expert in terrorism suggests that a deradicalization program, in a broad sense, should be approached in a more holistic manner. The program ideally should not not only try to change or eliminate the radical understanding alone, but also needs to re-arrange the social and economic life of the terrorists after being released from their custody. In addition to that, the government and

\footnotetext{
1 "Rekam Jejak Pelaku Bom Sarinah, Perampokan Bank Hingga Latihan Militer di Aceh,” http://megapolitan.kompas.com/read/2016/01/18/08541581/Rekam.Jejak.Pelaku.Bom.Sarinah.Perampokan.Bank.hingga.Latihan.Militer.di.Aceh accessed on 23 June 2016.

2 "Santoso dari Jantho jadi Gembong Teroris Poso," https://www.merdeka.com/khas/santoso-dari-jantho-jadi-gembong-teroris-di-poso-rekam-jejak-santoso-1.html, accessed on 23 June 2016.
} 
society also have to collaborate to minimize the spread of radical teachings among the society. This way, the terrorists will no longer have rooms to restore their previous radical idea. ${ }^{3}$ From my point of view, the failure to remove radical understanding is due to several factors. First, the very strong theological indoctrination of radical movements' leaders. Second, the abnormal psychologcial behavior of leaders and members of radical Islamic movements. Third, the lack of support for the social and political environment. ${ }^{4}$ Based on these three aspects, the de-radicalization program should be directed at changing the way of thinking, psychological condition and social environment. The question then, how this strategy can be implemented simultaneously?

To address the issues related to terrorism certainly requires workings in various sectors. However, the immediate thing that can be done is to cut the process of spreading the radical understanding. This cutting process will be effective when we focus on the strategic target and here is the through educational institutions. In this regards, it should be understood that the educational institutions themselves can not be assumed free from the radical movement. There are many research found that educational institutions actually play double roles. On the one hand, some of educational institutions are playing the roles in the de-radicalization and indoctrination of radical understanding. This is proved by the emergence of curriculum that promotes love to the nation among the youth, tolerance to others and respect for diversity. However, there also several schools are likely to contribute to the spread of the radical understanding. (REF)

In fact, the State Intelligence Agency (BIN), recently warned the public to be alert to varied ways used by radical groups in several educational institutions. BIN said that radicalism spread through (1) formal education lessons in radical Islamic boarding schools (2) the utilization of radical organizations network (3) education at the religion -focused university (4) the public sermons (5) books distributed free of charge (6) electronic media, such as television, radio, website and so

3 "Indonesia belum Punya Penanganan Terorisme yang Jelas," http://nasional. kompas.com/read/2016/06/29/00004011/indonesia.belum.punya.model.penanganan .terorisme.yang.jelas, accessed on 23 June 2016.

4 Nasaruddin Umar, Deradikalisasi Pemahaman Al-Qur'an dan Al-Hadis (Jakarta: Gramedia Kompas, 2014), p. 286. 
forth. (7) and social media owned by a particular organization. ${ }^{5}$ Actually, there were researches by Greg Fealy and Anthony Bubalo in 2001, before the warn by the BIN, that suggest that there are three main channels for the spread of radical movements in Indonesia; social movements, Islamic educational institutions and the publication of ideas through electronic, printed and social media. ${ }^{6}$

In addition, similar findings are also suggested by GP Ansor. Reviews by Akh. Muzakki in Kompas, dated on March 2, 2016 also assert the ideas of how the radical activists and tolerant groups spread their ideas trough organizations.. To give illustration, GP Central Ansor has found books containing the teachings of radical understanding in Depok, West Java. In the book, it was found vocabularies such as "Sabid (be a martyr) in Battlefields", "Finish Wins Slice Kiai (Islamic priest)", and other words. ${ }^{7}$ Similarly, Akh. Muzakki mentions in his books that the book material could be a threat to civic education in Indonesia and here they have violated the sacred ideals of national education systems. Therefore, it is the obligation of the state to allow the books being circulated among the students. ${ }^{8}$ So, the findings and reviews become concrete evidence that the deployment of radical teaching is visible in the media.

The above facts prove that educational institutions could play roles as the facilitator to promotion of the tolerant understanding and love to the nation; this has been already implemented by the Indonesian people for many years. Unfortunately, other facts show that the educational institutions also can be used as a media to spread the radical ideologies among the people of Indonesia. Therefore, this article will review three important things. First, it will discuss the linkage between educational institutions from the perspective of curriculum development within the educational institutions. Second, it will analyze the national curriculum and ways in which they can used

\footnotetext{
5 “Lawan Radikalisme dan Narkoba," Jawa Pos, 17 March 2016, p. 1.

${ }^{6}$ Greg Fealy and Anthony Bubalo, Jejak Kafilah, trans. Akh. Muzakki (Bandung: Mizan, 2007), p. 78.

${ }^{7}$ Kompas "GP Anshor Temukan Buku TK Berisi Kata Bom Jihad, Sabotase Hingga Gegana” http://edukasi.kompas.com/read/2016/01/20/14303871/GP.Anshor.Temukan.Buku.TK.Berisi.Kata.Bom.Jihad.Sabotase.hingga.Gegana?, accessed on 23 June 2016.

8 Akh. Muzakki, “Ancaman Pendidikan Kewarganegaraan,” Kompas, 2 March 2016, p. 7.
} 
by the teachers to teach radical understanding. Third, it will try to promote a paradigm and a collective commitment to eliminate the radical understanding within educational institutions, so as to create a tolerant society embracing the idea that Islam is Rabmatan lil 'Alamin.

\section{Decomposition of the politics of Islamic education curriculum and the spread of Radicalism}

Educational experts believe that the curriculum has a role as important as school climate, leadership and competency/professionalism of teachers, in delivering the lesson. The curriculum, on the one hand, will indicate the direction to which learners grow and will reach their goal in educational institutions. On the other hand, the curriculum is also a standard of action that must or should be done by an educator to the student. For that reason, the curriculum is always used as a double-guidelines for both teachers and institutions in planning and implementing the teaching and learning process in educational institutions.

Philosophically, the curriculum must be able to respond to the circumstances; building the character of the students as well as accumulating renewable knowledge to equip learners in their real social life. Politically, it has to be admitted that the curriculum, is the government's blueprint to shape and prepare the next generation of the nation. Therefore, the authority to formulate the curriculum is still the prerogative rights of the central government, at least in deciding the basic competencies and competence standards to be achieved by students. ${ }^{9}$ In the Law on National Education System (Education Law 2003) it is stated that, in order to achieve the educational goals, the formulation, development, and implementation of the competencybased curriculum have to include attitudes, knowledge, and social skills in accordance with the national standards that have been agreed upon .${ }^{10}$ In the context of national life, the value of competency that leads people to become good citizens have been the core competency that must be built and developed in the national curriculum.

Here, it is clear that curriculum is very vital in in determining the direction of an educational processes. It is also important to note that

\footnotetext{
9 Nana Syaodih Sukmadinata, Pengembangan Kurikulum Teori dan Praktek (Bandung: Remaja Rosdakarya, 1997), pp. 51-52.

${ }^{10}$ Law no. 20/2003 on National Education System.
} 
the spread of radical Islam has been assembled, planned, and implemented using the design of the systemic and systematic curriculum, particularly in public educational institutions or Islamic educational institutions. In both institutions, curriculum can be in written curriculum and hidden curriculum. in the public schools where the PAI curriculum, generally, the derivative part of the national curriculum design, will be made in written and factual form. It means that the subject matter and all aspects of curriculum will be written curriculum and delivered as process of documentation of basic competence, competency standards, and indicators of the success of the learning process carried out by a teacher to his student. On the other side, the hidden curriculum is a context design, content delivery, and value of the teachings delivered without being known by others. Like, teachers, tausiyah (preached advices) delivered by a kiai (Spiritual leader) to his students.

Two Islamic religious education curriculum categorization presented above are in line with the results of research by Charlene Tan conducted at an Islamic boarding school in Ngruki, Solo, and in Pondok Pesantren Tebuireng, Jombang. In Ngruki, the construction of both curriculum, written or hidden, has been aimed to direct the students to be part of the movement to uphold Islam religion and as a political system in Indonesia. In Tebuireng, both types of curriculum are designed as a base to foster tolerance, moderates and love of country and nation. Charlene Tan also said that, in Ngruki, materials on fostering ideology and indoctrination of Islamic state can be found in some of the text-books distributed to all students at junior [SMP] and senior high schools [SMA] specifically on the subjects of theology, fiqh [Islamic law], and other Islamic textbooks. ${ }^{11}$ Meanwhile, indoctrination through the hidden curriculum in the form of learning culture is based on the aspects of mologis. This means that the students are prohibited from 'refute' or disagree with whatever presented by the teachers. The close relationship between teachers and students has been the means to seamlessly facilitate rapid transformation of the teachers' beliefs within students minds subconsciously. All these then got its final validation and strengthening from speeches and directives (tausiyah) from the Pondok Pesantren leader, Abu Bakar Ba'asyir,

${ }^{11}$ Charlene Tan, Islamic Education and Indoctrination; The Case In Indonesia (New York; Routledge, 2011), p. 52. 
amplify the entire systematic and process of knowledge and ideology transfer. ${ }^{12}$

In addition, Charlene Tan argues that different conditions seen in Tebuireng Pesantren (Islamic boarding school) in Jombang. The curriculum design is not very different from that of Ngruki; that is through written curriculum and covert approach. However, the content and teaching are significantly different. At the school founded by KH. Hasyim Ashari, national education system and its curriculum is adopted. The system is integrated in the order and system of values taught to the students at the boarding school. ${ }^{13}$ From her observations, the condition and characteristics of the learners in Tebuireng tend to be more friendly and polite when communicating to the guests who come to their school, despite their different backgrounds and interests.

Before the study by C. Tan, other researchers such as Robert W. Hefner, ${ }^{14}$ Noorhaidi Hasan, ${ }^{15}$ Martin Van Bruinessen, ${ }^{16}$ Greg Fealy and Anthony Bubalo, ${ }^{17}$ suggest that there is a massive constructionism using systematic approach (curriculum) in the management of the boarding schools identified as deploying the ideology of radicalism. For that reason, recommendations and suggestions made at the end of their research report are similar,.First, the recommendation adressses the connection between those schools with transnational movement network. The connection here comes in various forms be it in the assistance to the establishment processes or other aspects such as the management of educational institutions. Second, it addressee's the curriculums particularly in the written one. It is suggested that it is necessary that all reading materials given to the students are to be

\footnotetext{
12 Ibid., pp. 53-58.

13 Ibid., p. 70.

14 Robert W. Hefner, "Islamic School, Sosial Movement, and Democracy in Indonesia," Robert W. Hefner (ed.), Making Modern islam Politic of Education in South Asia (USA: Hawaii University Press, 2009), p. 58.

15 Martin van Bruinessen, "Traditional and Islamist Pesantrens in Contemporary Indonesia," Farish A. Noor, Yoginder Sikand, and Martin van Bruinessen (eds), The Madrasa in Asia; Political Activism and Transnational Linkages (Amsterdam: Amsterdam University Press, 2008), pp. 217-218.

${ }^{16}$ Noorhaidi Hasan “The Salafis Madrasah in Indonesia," in Ibid., p. 247.

${ }^{17}$ Fealy and Bubablo, Jejak Kafilah, p. 94.
} 
monitored. Third, it is asserted that there is a necessity to observe the transfer of Islamic values through the daily behavior of the leaders of the institutions. Fourth, it warned all sectors to be wary of the construction of educational curriculum geared to the interests of forming radical characters.

Among Indonesia researchers, it seems that not many researchers suggest the construction of the educational curriculum, as part of the medias play roles in spreading the radical Islam. This is because they see that the system of curriculum development is still centralized and formulated by the government. This condition, Hence, they assume that given the materials component to students, is in accordance with the philosophical basis of nationality, ideology, sociology, and juridical. Indonesian researchers tend to look at two aspects that could alter the formulation of the curriculum that is taught in educational institutions, they are the teachers as interpreter to the formulation of a general curriculum and the writers who compose the books or reading materials distributed to students as a learning medium. A study by Abu Rokhmad conducted in several schools in Semarang concludes that the spread of radical understanding through educational institutions could be due to the ways in which some teachers interpret some of the themes listed in the Islamic Education Curriculum (PAI) in line with their radical ways of thinking and then present and teach them to the students. In addition, the spread can also be through the reading materials distributed to students be it in the form of specific themes depicted radical understanding, or even inserted in the exam items for students. ${ }^{18}$

\footnotetext{
18 Abu Rokhmad research describe that there are two major themes or topics in the student workbook, which will be considered as militant and 'radical' language use. Firstly, obligation to young Moslem to build and create an Islamic political systems and laws. Secondly, obligation to all student to wear and to act based on syar'i rules. In addition, these topics is instrumented and derived as subject items on exam. Abu Rokhmad showed an example of them seem like; "what kind of Islamic law perspective, if someone against to build and create Islamic Political System and Law, according to Islamic teaching?". Based on this teaching learning process, Abu Rokhmad warn every teachers to examine and contextualize these subject themes, to Indonesian plural society. In order to no student have split understanding that Islami willing to create Islamic society like radical movement and so on. This study held on SMA/SMK in Semarang City with textual and teachers understanding approaches. See Abu Rokhmad, "Radikalisme Islam dan Upaya Deradikalisasi Paham Radikal" Jurnal Wali Songo, No 1 (2012), p. 79.
} 
Different from Abu Rokhmad Wahyudi et al, in the Journal of Maarif Institute, argue that radicalization in educational institutions spread through several ways and they are including activities of building strong religious character with intentionally leaving the message of the importance of embracing nationalism. Another way is using the social setting such as the strengthening of the radical understanding among groups and classes in the neighborhood. ${ }^{19}$ This condition, if associated with the research by Charlene Tan, actually is the manifestation of a hidden curriculum. The teachers and school stakeholders embracing radical paradigm and frame an atmosphere or a learning climate that tends to negate the ideas of patriotism and love to the nation. Mostly, it is staged at the beginning of the students life in the instituions using activities to study Islam in the early days of the new student orientation. Furthermore, it should also be recognized that teachers and friends also play role in articulating the idea of conversion to Islam, so eventually it becomes the principle that is difficult to be amended by the views of others.

In the same journal, Ahmad Gaus AF, map out how the students/learners begun to know and then internalize the radical ideas. He points out the fact that the school has allowed groups like Hisbut Tahrir Indonesia (HTI) to put their brochure on the walls of the school is actually contributing to the development of the radical views among the students.

Fortunately, Their call to enforce the Caliphate and reject Pancasila and the Indonesion Constitution as well as the Republic of Indonesia (NKRI) seem to have no significant result yet. In other words, the ideas of islamic state and others including rejecting Pancasila have not yet succeeded in persuading people in general even in areas that have already applied apply Sharia legislation such as Cianjur and Pandeglang. Yet, they still promote their ideas trough media. For example, they distribute bulletins of HTI in large schools possessing fairly large library in Yogyakarta and Solo. Even in the library of SMAN 1 Yogyakarta (a public school), there are many books of the Muslim Brotherhood (Ibwanul muslimin), Sabili magazine, and similar magazines donated by the alumni delivered through Rohis activists. "20

19 Wahyudi Akmaliah M and Khelmy K. Pribadi, "Anak Muda, Radikalisme, dan Budaya Populer," Jurnal Ma'arif Institute, Vol. 8, No 1, (2013).

${ }^{20}$ Akhmad Gaus AF, "Pemetaan Problem Radikalisme di SMU Negeri di 4 Daerah," Jurnal Ma'arif Institute, Vol. 8, No 1 (2013), p. 174. 
Ahmad Gaus AF also added explanation on the HTI's ways of recruiting, campaigning radical ideology, and teaching it systematically. They found that promoting the ideas through PAI curriculum taught in schools is one of the strategies developed and run by such groups. This is indicated by the existence of teachers of this subject who are members of the group. This is found in four regions where he conducted his studies. Therefore, for the sake of maintaining the nationalism among the students, Gaus recommended to the principal to be more selective in choosing teacher of Islamic education in their schools. ${ }^{21}$

The pattern is similar to the phenomenon of radicalism among students. M. Zaki Mubarok, in his study, has revealed that there is a change of paradigm among the students in UIN Syarif Hidayatullah Jakarta and this is due to many factors. There are various levels of the changes among the students. He found that the growing trend of radicalism in UIN Syarif Hidayatullah Jakarta is more likely because many new students come from public high schools as there is an increasing number of non-Islamic studies departments in UIN Jakarta. There is a declining number of students, at least in the percentage, come from islamic boarding schools like in the past. Another ways is the strengthening of student organizations embracing radical understanding in campus. Such organizations have started competing against mainstream Indonesian student organization. ${ }^{22}$ It is widely know that UIN Jakarta was shocked in 2011 by the fact that one of the alumnus became suspects of terrorism acts. The rector of UIN Jakarta, at the time, Komarudin Hidayat clarified the case and stated that the terrorist behavior, as shown by that particular alumni, was not because of the curriculum in the university. Rather, as he explained, this is due to the influence the perpetrators got when they are affiliated with radical organizations existed on the campus.

From the data presented above, it can be concluded that education is not a sacred area that cannot be penetrated and infiltrated by the radical understandings and views that 'deviate' from the idealism of embracing Indonesian-Islam. As a matter of fact, the institution could be a transitional tool for this movement. In the author's view, at least,

\footnotetext{
${ }^{21}$ Ibid., p. 175.

${ }^{22}$ M. Zaki Mubarak, "Dari Semangat Islam menuju Islam Radikal," Jurnal Ma'arif Institute, Vol. 8, No 1 (2013), p. 192.
} 
there are three important lesson learned from the phenomenon related to association between radicalism and essential elements within education. First, the radicalism is promoted and taught through the institutional system and the design of curriculum directed to build radicalism in the character of the students. In this case, the result will be that the radicalism will manifest within the students minds and character and will be very difficult to change. Second, radicalism will develop due to the perspective of educators (Religion teachers) that emphasizes radical mindset. Third, it is important to note that, despite the desire of the state to promote a multicultural model-based education and promote national character, the fact that radical groups do exist within the schools.

Therefore, one solution to address the issue is to establish uniformity of vision, mission, and goals in order to frame education in Indonesia to be more tolerant, based on plural culture, religion, and religious understanding. In addition to that, it is also important for all stakeholders and the academic community within the educational institution to be more cautious towards certain groups who are proven to be threat to NKRI. Furthermore, I also see the necessity to put clear scope in relation to what actually the ideal model of Indonesian Islam that should be taught to the students. This is important so there will be no more conflicting interpretation that, in contrast, promote the anti nationalism and anti-Indonesian Islam.

Therefore, in the following discussion I will attempt explore 'problematic' topics within the curriculum of Islamic education which can be used as tools and medias to promote radicalism in Indonesia, Additionally, it will also try enrich the explanation with exposing commonly agreed and know views of Islam in Indonesia.

\section{Competency Map of PAI curriculum in Indonesia}

The previous section has presented the strategies of the radical groups in spreading their radical understanding and their expression of understanding through educational institutions. In this section, I will propose a map of core competencies of Islamic Education based on Curriculum of 2013 in high schools in Indonesia. In addition, I will also explain some of the themes of discussion that are often used as tools to foster radical views and attitudes among the students. Setyo Hartanto describes core competence map of Curriculum 2013, in general, in the following table: 
Table 1. Components of Core Competence in High School/Madrasah Aliyah

\begin{tabular}{ll}
\hline No & \multicolumn{1}{c}{ The core competencies of Class X, XI, XII } \\
\hline 1 & Living and practicing the teachings of their religion \\
\hline 2 & $\begin{array}{l}\text { Living and practicing honest behavior, discipline, responsibility, caring } \\
\text { ("gotong royong", cooperation, tolerance, peace), being courteous, } \\
\text { being responsive, being proactive, taking part in search of the solution } \\
\text { to various problems, interacting effectively with social environment } \\
\text { and with nature, and being able to position themselves representing the } \\
\text { nation in global society. }\end{array}$ \\
\hline 3 & $\begin{array}{l}\text { Understanding, implementing and analyzing factual knowledge, } \\
\text { conceptual knowledge and procedural one based on their curiosity } \\
\text { about science, technology, arts, and culture in the perspective of } \\
\text { humanity, nationalism, state, and civilization in association with the } \\
\text { roots of causes of the phenomenon within the work-field to solve the } \\
\text { problems }\end{array}$ \\
\hline $\begin{array}{l}\text { Processing, reasoning, and presenting the concrete and the abstract } \\
\text { realm associated with the development of learned at school } \\
\text { independently, and are able to carry out specific tasks under direct } \\
\text { supervision. }\end{array}$ \\
\hline
\end{tabular}

If you look at the four components above, of course, no one can deny that, linking national education curriculum with the spread of radicalism, imposes an apologetic attitude and unfounded. It is because the maps of competency has been prepared based on aspects of the philosophy of the Indonesian nation pluralistic ideology, Pancasila. It advocates to embrace all people, social conditions (sociological aspect) of Indonesian people who want to work together in everyday life, as well as in the legal basis, whether in terms of teleology the national education system or the Indonesian national education standards.

Nevertheless, after the decentralization of educational authority, including in the process of development and expansion of curriculum materials, the central government are not able to challenge the construction of curriculum taught at the micro and macro level. The teachers and their school have their own consortium to interpret the blue print of the curriculum developed by the central government. In the drafting process at this level, radicalism can be potentially introduced and taught to students. Such introduction can take many forms, ranging from embedded in the basic competence, teaching materials, themes for discussion, or questions provided by the teachers to the students, as well as cases that are already described in the 
previous discussion. For this reason, the author considers that it is important that there are concrete limits imposed to people who have the right to develop the educational curriculum, at least on the five themes (read: basic competence) in the 2013 curriculum. Such limitation is to assure that the goals of national education, and the goals of learning do not have discourse discontinuity.

The five themes are first, an explanation of the schools of theology in Islam, in class XI in Madrasah Aliyah [Senior Islamic High School level]. This theme, I believe, is potentially risky for misinterpretation. It is because today, the schools of classical Islam has begun to be modified into two models; moderate and takfiri (extremely exclusive). If the introduction of the schools of Islamic theology framed in the realm of building ideology that upholds pluralism as grace, then it will not make students have a different view. Pluralism and differences in Islam are considered as a form of destiny attributed to the will of God the almighty. However, conditions will be slightly different if, in the phases of presentation, students are introduced to history of political conflict caused by difference in theology. Then, Islam will be known and identified as a religion that justifies violence in the deployment of their respective ideologies, For example, the introduction of a conflict between the views of the Kharijites, supporter of Muawiyah, and the Shiite leadership in the era of caliph Ali ibn Abi Talib. or a bloody conflict between the Sunni-Shiite-Wahabi in the Middle East, today.

For that reason, what needs to be introduced to the students is a form of thought alone, without addressing the conflicts that are present in the political aspect. Despite going to be explained, then it should also be introduced that Indonesia, as a country, have the obligation to bring a sense of security to all schools of theology existing and developing in Indonesia. It is indispensable to introduce students to the context of theological schools in Indonesia to negate the impressions of anarchy echoed by the radical group through their respective media, for instance there is a Salafi-Wahhabi website that is always campaigning anti-Shiite movement in Indonesia.

Secondly, the Islamic caliphate, at the Figh (Islamic law) subjects in Class XII Madrasah Aliyah is most vulnerable, among several themes that are taught prior to this theme (read: Related to the perfection of Islamic laws regulating all aspects of human life) or after (read; related to the processes of formation of Islamic law, in the version of the science of usulfigh). It is because the terms used in the elaboration of 
competence essentially resembles indoctrination which is often performed and propagated by the majority of radical groups in Indonesia, for example the word caliphate and jihad terminology. The following table will explain the two components of core competence and basic competences related to the theme of the obligation to implement Islamic law.

Tabel 2. Core Competence and Basic Competence Subjects Figh

\begin{tabular}{|c|c|}
\hline Core Competence & Basic Competence \\
\hline $\begin{array}{l}\text { Appreciating and practicing their } \\
\text { religion }\end{array}$ & $\begin{array}{l}\text { 1. Appreciating the wisdom in Islamic } \\
\text { caliphate } \\
\text { 2. Believing in the glory of jihad in the } \\
\text { path of God. } \\
\text { 3. Believing in the truth of Islamic law } \\
\text { 4. Believing in the ability of ijtihad as a } \\
\text { gift from God } \\
\text { 5. Accepting the truth of the syar'i law }\end{array}$ \\
\hline $\begin{array}{l}\text { Appreciating and practicing } \\
\text { honest behavior, discipline, } \\
\text { responsibility, caring (gotong } \\
\text { royong, cooperation, tolerance, } \\
\text { peace), polite, responsive, } \\
\text { proactive, and to be part of the } \\
\text { solution to many problems in } \\
\text { interacting effectively with the } \\
\text { social, environmental, and can } \\
\text { position itself as a national } \\
\text { reflection in the social world. }\end{array}$ & $\begin{array}{l}\text { 1. Having honest behavior, discipline, } \\
\text { and responsibility for the } \\
\text { implementation of the understanding } \\
\text { about the Caliphate } \\
\text { 2. Demonstrating courage in defending } \\
\text { the truth as the implementation of } \\
\text { the understanding about jihad } \\
\text { 3. Having tolerance and mutual respect } \\
\text { as the implementation of the } \\
\text { understanding about muttafaq } \\
\text { (undisputed) and mukhtalaf } \\
\text { (disputed) sources of Islamic law } \\
\text { 4. Demonstrating the love to science as } \\
\text { the implementation of ijtihad (Islamic } \\
\text { legal reasoning) } \\
\text { 5. Demonstrating an attitude of obedi- } \\
\text { ence to the rules occurring as the } \\
\text { implementation of the understanding } \\
\text { of the concept of law in Islam }\end{array}$ \\
\hline $\begin{array}{l}\text { Understanding, applying and } \\
\text { analyzing factual knowledge, } \\
\text { conceptual and procedural based } \\
\text { on curiosity about science, } \\
\text { technology, art, culture, and } \\
\text { humanities in the vision of }\end{array}$ & $\begin{array}{l}\text { 1. Study the problem of Islamic rules of } \\
\text { government (caliphate) } \\
\text { 2. Understanding the concept of jihad in } \\
\text { Islam } \\
\text { 3. Identifying the sources of Islamic law } \\
\text { muttafaq and mukbtalaf }\end{array}$ \\
\hline
\end{tabular}




\begin{tabular}{|c|c|}
\hline Core Competence & Basic Competence \\
\hline $\begin{array}{l}\text { humanity, national, state, and } \\
\text { civilization-related to the causes } \\
\text { of phenomena and events in the } \\
\text { field of specific work to solve } \\
\text { problems }\end{array}$ & $\begin{array}{l}\text { 4. Explaining the meaning, function, } \\
\text { and position of ijtibad } \\
\text { 5. Understanding the concept of syar'i } \\
\text { law in Islam (aljudge, al-bukm, al- } \\
\text { Mabkum fih and al Mubkam) }\end{array}$ \\
\hline $\begin{array}{l}\text { Processing, reasoning, and } \\
\text { presenting the concrete and the } \\
\text { abstract realm associated with } \\
\text { the development of the lessons } \\
\text { learned in school independently, } \\
\text { and able to carry out specific } \\
\text { tasks under direct supervision. }\end{array}$ & $\begin{array}{l}\text { 1. Presenting examples of applying the } \\
\text { fundamentals of the caliph } \\
\text { 2. Presenting correct examples of jihad } \\
\text { 3. Presenting concept map the Islamic } \\
\text { law that is muttafaq and mukbtalaf } \\
\text { 4. Presenting condition of becoming a } \\
\text { mujtabid (muslim jurist) } \\
\text { 6. Making an example of the various } \\
\text { taklifi and wad'i law }\end{array}$ \\
\hline
\end{tabular}

In the narration of competence above, it is firmly stated two terms (jihad and caliphate), that if infiltrated by the perspective of radical understanding, can lead to the misunderstandings and abandoning of the main purpose of the national education system. The first word is wisdom in the Islamic caliphate. As a discourse, It describes that Islam had had a political leadership model in the era of khulafa al Rashidin (four guided caliphs), after the death of the Prophet Muhammad, and the model retain the persistence of Islamic law as rules of thumb, and that is true. This is to say that actually, there are many lessons that can be learned from caliphate system implementation (Islamic leadership) in managing their own civilization. However, it will be a little contrary, if the discourse was indoctrinated as an understanding obligating the Muslims to establish that very identical model. This is because the condition of Islam in the era of sababat (prophet companions) and todays' condition of Islam is different. Social issues, politics, and global interests is no longer relevant, if seen in the light of the classical paradigm. Therefore, the authors of this curriculum, in the last section, put forward critical attitude and look for concrete examples of contemporary caliphate. The goal is to change the mindset of the learners that is related to the discourse construct that existed previously.

Ironically, what happened today, the theme is likely to be cut and directed at the cognitive-practical aspects, without any critical value. This theme, as discussed by Abu Rokhmad, is the sexiest theme for a teacher embracing radical paradigm to confirm the truth of his or her 
thinking, even though, there are still many teachers who set limitation to the concept of the caliphate as an Islamic political system. ${ }^{23}$ Therefore, an important point that the author wants to emphasize here is that such a sensitive theme should be paired well with the enrichment and contextualization of the process of establishing Islamic law that exist and be implemented in Indonesia. Furthermore, if needed, this theme can be assigned to the students, who have more religious understanding and critical reasoning. In other words, the use of this strategy on this theme can be implemented only in certain institutions, not all Islamic educational institutions. For example, the themes, which are problematic, are explained to the students who live in the Islamic boarding schools, because of the dynamics and the intensity of Islamic studies there is broader than at school or madrasabs [Islamic schools].

Second term, based on the basic competence as mentioned above, is the word Jihad. Historically, I do not have objection with the obligation to carry out jihad in the cause of Allah. This is because jihad is just like the obligation to implement Islamic law (read; values greater than Islamic law). The obligation of jihad is founded on the value of the text of Quran. However, in the current context, the word jihad in Allah's way is no longer easily translated in the form of concrete action. However, the meaning of jihad has been reduced as activity against oppressing tyranny, as practiced by Muslim radicals. Again, teachers seem highly required to have a holistic understanding of relevant terms of this curriculum. Jihad meant in this curriculum competence should be expanded as a form of social obligation of sharing, helping, and fighting against the passion of anger that is more valuable than physical jihad against the enemy. Two sensitive terminologies above, which framed the writer's thought about the fear of students being introduced to the radical ideologies that exist in Indonesia.

The Third is the human duty as caliph (leader), in the Competency Standards of Qur'an and Hadith subject for Class X Madrasah Aliyah and a theme in fiqh subject for class XII is about Islamic Leadership and Implementation of Islamic Law (siyasah syar'iyab). Just like in the previous theme, the word leader, in the majority of the real world

\footnotetext{
${ }^{23}$ Abu Rokhmad, "Radikalisme Islam dan Upaya Deradikalisasi Paham Radikal," Jurnal Wali Songo, No 1 (2012), p. 79.
} 
conditions of the majority, is always juxtaposed with tyranny and hegemony against minorities. The impact of the way of such thinking is of course, will lead towards arrogant actions against those who have different views.

The fourth is the study about the leaders of reformation and enforcement of Islamic Sharia, in the Islamic History (SKI) subject for Class X Madrasah Aliyah. Jamaludin Al Afghani, Muhammad Abduh, Ibn Taymiyyah, Hasan al Bana and other reformist leaders are figures who are introduced to students as part of the Islamisation process in their respective countries. Indeed, students do need to know their history and roles in Islamic reforms. Provided, leadership and reform program that they campaigned are contextualized in a particular space or territory, and are not applied globally. Leadership virtues presented in the struggles of the characters mentioned above should be placed in the context of an example or universal role model and should not be necessity to be duplicated.

By that way thinking, then figures like Jamaludin Al Afghani, Muhammad Abduh, and Ibn Taymiyyah are perceived as Muslim reformers who could move people to free themselves to find freedom from cultural colonialism, unorthodox dogmas, and hegemony. However, that does not mean the system that they embed, after winning the struggle against colonialism, could be duplicated into a system that should be implemented in Indonesia. Because Indonesia has own Muslim native thinkers and reformers who lived, fought, and upheld the values liberation such as Suminar, KH. Ahmad Dahlan, and KH. Hasyim Ash'ari.

The Fifth is the obligation of al-amr bi al-ma'ruf wa al-naby 'an almunkar (commanding the good and forbidding the evil), in the subject Aqidah Akblaq in Madrasah Aliyah. Similar to the question of the obligation to implement Islamic law, liabilities invite to do good, and forbidding Muslims from doing evil, will lead to an understanding of the text. For groups of tolerant, the word amar is interpreted as solicitation process through persuasive ways to achieve happiness, as well as an invitation to stay away from the prohibited. On the contrary, radical groups interpret the word amr and naby mean order as the imposition of will to follow and will do everything they can to achieve it.

Understanding of the word al-amr bi-al-ma'ruf and naby 'an al-munkar will not specifically cause a radical understanding (read: terrorism). Such understanding will lead learners to think the way radical groups 
do. They tend to disregard government system and to bring about vigilantism in preaching Islam. Therefore, contesting and discussing these two perspectives are easier. That is, by way of invitation and contextualization approach as exemplified in ways that are persuasive (invitation through friendly attitude), then rejection of wrong missionary endeavor which lead to coercion, instability and conflict in the community.

\section{Re-education/re-viewing of Islamic Understanding and Commitment towards Counter Radicalization}

Due to the potential bias in the meaning of the concept, I deliberately leave the term de-radicalization of radical understanding as a strategy to minimize the Islamism through educational institutions. ${ }^{24}$ Moreover, the term actually is inappropriate to be associated with the educational institutions that actually is the media for knowledge transfer as well as character building of the learners of the next generation and has no history of having any association with groups of radical Islamism. The use the term re-education in understanding Islam, at first, should address the educators in relation to the curriculum designed by the government. Based on the idea of the sociology in education, educational institutions should at least have three aspects. First is the ideological values as the school, as the educational institution, should have ideological values. Second, the format of knowledge that begun so general in frame and then screened to be selected in accordance with the purpose of the educational institutions. Third, the educators who run the selection process of the transmission of the science. ${ }^{25}$

As an educational institution, schools have an obligation to echo the national ideology and the great values owned by Indonesians. In this frame, suspecting that Islamism is propagated institutionally is weak. Although there are few studies showing that there are educational institutions, of which the management expenses are funded by foreign donors, do embrace radical Islamic ideology. Yet, this phenomenon is hard to find among the public educational

\footnotetext{
${ }^{24}$ Masdar Hilmy, "The Politics of Retaliation; The Backlash of Radical Islamist to deradicalization Project in Indonesia" in Al Jami'ah, Volume 51, No. 1 (2013), p. 130.

${ }^{25}$ Basil Bernstein, Class, Codes and Control; Toward a Theory of Educational Transmission (London: Routledge, 1975), p. 158.
} 
institutions in Indonesia. Actually, as I already explained above, there is a quite uniform standard of the knowledge and curriculum within the educational institutions in Indonesia. Hence, if we read the formal aspects and normative component of the content standards and competency standards as well as the reading sources in the curriculum of 2013, it is quite hard to link the curriculum to the development of radical understanding and radical movements in Indonesia.

The stakeholders of the development of the curriculum who are appointed by the government will definitely base their selection of the knowledge or materials being taught in line with, or even support, the national education goals. Among the goals are educating the children of the nation, contributing to economic development, and assisting the character building for the generation to have the noble characters.

Nonetheless, concerns and worries about the misuse of the curriculum that is aimed at achieving the goals mentioned above are legitimate. This is due to the fact that schools have three aspects that can be used by other power to meet their goals. The first is related to how regulations are implemented by educational institutions on a daily basis. This question, according to M. Apple, is associated with the hidden curriculum embedded in activities of the students, teachers, and other educational elements. In addition, there is also another issue of how the design of the curriculum that is being used by schools as their guidelines in delivering the learning process. The third aspect, which is the most important, as pointed out by M. Apple, is the perspectives of teachers towards the ideologies developed within the educational institutions. The last aspect is very important since the teachers play roles as the role models, guidance, and agents for the transmission process of knowledge and views to the learners. ${ }^{26}$

Therefore, it is very likely that the changing trend of the views within the educational institutions, from the tolerant understanding to radicalized ones, it is mainly more due to two things. First thing is the hidden curriculum (acts of situating), exist in educational institutions. Here, the hidden curriculum, can be run institutionally or more like a sporadic one by actors (agency) within the schools without systemic support from the institution. Second thing that is also likely the causing factor behind the changing trend of views within the school is

${ }^{26}$ Michael M. Apple, Ideology and Curriculum (London; Routledge Falmer, 2004), p. 1213. 
the ideological understanding of the teachers. The ideological-biased understanding of the teachers that is being transferred to the learners and lead to the ways in which their views are shaped or even transformed. In other words, there is a high potential abuse of the text by the teachers. They can present the material, that might be neutral, in a biased perspective which, unfortunately, are leaning more to the favor of radical Islamism.

Therefore, re-educating the understanding of Islam is very important for teachers of Islamic religion education whether in the public educational institutions or in Islamic schools. It is due to the fact that the teachers still see the state and Islam is a dichotomous way of thinking. This view is closely related with their knowledge and educational background. Affiliation with radical groups is also determinant factor. As explained by Komarudin Hidayat, there are several students in certain universities who are affiliated to radical movements existing around the campus.

Re-educating the educators could also be interpreted as a commitment to create a new society that is tolerant and have a friendly understanding of Islam through the teaching and learning of Islamic Education. When linked with the context of the curriculum, teachers should read the Islamic curriculum from the point of view of Pancasila as state ideology. In other words, the reading of Islam should be using the perspective of kenusantaraan (nationalism) and plurality in Indonesia. In addition, the commitment also should be about framing the curriculum development process in educational institutions as a system of ideological control. This being said, the existing curriculum in educational institutions should be in line with national education goals. Such models, actually, are often carried out by developed countries to create a reproduction of a new society. The leaders of the State create a system by which screen and control the educator recruitment process through varied ways from the certification of teachers, strengthening of the competence to the process of social competence and responsibility. Without such systemic efforts, the responsibility of educational institutions to maintain the unity of ideology and the values as the nation as well as the governance system are in risk threatened by the radical groups. 


\section{Conclusion}

In conclusion, the curriculum is the text function as a guide for educators in performing their roles and functions as transmitters of knowledge to the learners. Because it is text, and only the teachers are the ones who know and can interpret the meaning of it, the issue then is to promote the ways in which the texts are interpreted in accordance with the attitude of professionalism; be it in the frame of academic competence, social, and professional. The curriculum is not the teaching materials that are read by the teachers. Rather, the existence of teaching materials should derived what has been specified in the curriculum.

The phenomenon of the spreading radical Islamic understandings through the educational institutions are evident in Indonesia. As the thread becomes more dangerous, several efforts need to be formulated.

One of the efforts or strategies that can be employed to 'eliminate' radical understanding of Islam and radical movements in educational institutions is through the process of re-education, building a shared commitment and blocking radical ideologies to be part of the educational institutions in Indonesia. All these efforts can be accelerated by understanding both the potentials and risks of elements within the educational institutions. Among the strategies are perfecting the understandings of the curriculum that has bias in meaning and can be misused, reviewing and redesigning the, peaceful and tolerant Indonesian Islam.]

\section{References}

\section{Books and Articles}

Akmaliah M, Wahyudi and Khelmy K. Pribadi. "Anak Muda, Radikalisme, dan Budaya Populer." Jurnal Ma'arif Institute, Vol. 8, No 1 (2013).

Apple, Michael M. Ideology and Curriculum, London; Routledge Falmer, 2004.

Beirnstein, Basil. Class, Codes and Control; Toward Theory of Educational Transmition, London: Routledge, 1975. 
Fealy, Greg and Anthony Bubalo. Jejak Kafilah, trans. Akh. Muzakki, Bandung: Mizan, 2007.

Gaus AF, Akhmad. "Pemetaan Problem Radikalisme di SMU Negeri di 4 Daerah." Jurnal Ma'arif Institute, Vol. 8, No 1 (2013).

Hasan, Noorhaidi. "The Salafis Madrasah in Indonesia." Farish A. Noor, Yoginder Sikand, and Martin van Bruinessen (eds). Madrasa in Asia; Political Activism and Transnational Linkages. Amsterdam; Amsterdam University Press, 2008.

Hefner, Robert W. "Islamic School, Social Movement, and Democracy in Indonesia." Robert W. Hefner (ed.). Making Modern Islam Politic of Education in South Asia, USA: Hawaii University Press, 2009.

Hilmy, Masdar. "The Politics of Retaliation; The Backlash of Radical Islamist to deradicalization Project in Indonesia." Jurnal Al Jami'ah, Volume 51 No. 1 (2013).

Law No 23/2003 on National education system.

Mubarak, M. Zaki. "Dari Semangat Islam menuju Islam Radikal." Jurnal Ma'arif Institute, Vol. 8, No 1 (2013).

Rokhmad, Abu. "Radikalisme Islam dan Upaya Deradikalisasi Paham Radikal." Jurnal Wali Songo, Volume No 1 (2012).

Sukmadinata, Nana Syaodih. Pengembangan Kurikulum Teori dan Praktek. Bandung: Remaja Rosdakarya, 1997.

Tan, Charlene. Islamic Education and Indoctrination; The Case In Indonesia. New York: Routledge, 2011.

Umar, Nasaruddin. Deradikalisasi Pemahaman Al-Qur'an dan Al-Hadis. Jakarta: Gramedia Kompas, 2014.

van Bruisennen, Martin. "Traditional and Islamist Pesantrens in Contemporary Indonesia." Farish A. Noor, Yoginder Sikand, and Martin van Bruinessen (eds). Madrasa in Asia; Political Activism and Transnational Linkages. Amsterdam; Amsterdam University Press, 2008.

\section{Newspapers and Internet Sources}

"Indonesia belum Punya Penanganan Terorisme yang Jelas," http:/Lnasional.kompas.com/read/2016/06/29/00004011/indonesi- 
a.belum.punya.model.penanganan.terorisme.yang.jelas, accessed on 23 June 2016.

“Lawan Radikalisme dan Narkoba," Jawa Pos, 17 March 2016, p. 1.

"Rekam Jejak Pelaku Bom Sarinah, Perampokan Bank Hingga Latihan Militer di Aceh," http://megapolitan.kompas.com/read/2016/01/18/08541581/Rekam.Jejak.Pelaku.Bom.Sarinah.Perampokan.Bank.hingga.Latihan.Militer.di.Aceh accessed on 23 June 2016.

"Santoso dari Jantho jadi Gembong Teroris Poso," https://www.merdeka.com/khas/santoso-dari-jantho-jadi-gembong-teroris-diposo-rekam-jejak-santoso-1.html, accessed on 23 June 2016.

Kompas "GP Anshor Temukan Buku TK Berisi Kata Bom Jihad, Sabotase Hingga Gegana" http://edukasi.kompas.com/read/2016/01/20/14303871/GP.Anshor.Temukan.Buku.TK.Berisi.Kata.Bom.Jihad.Sabotase.hingga.Gegana?, accessed on 23 June 2016. 
Husniyatus Salamah Zainiyati

$\mathbf{3 0 8}$ JOURNAL OF INDONESIAN ISLAM

Volume 10, Number O2, DECEMBER 2016 